\title{
Sweet As Sugar-Efficient Conversion of Lactose into Sweet Sugars Using a Novel Whole-Cell Catalyst
}

Shen, Jing; Chen, Jun; Jensen, Peter Ruhdal; Solem, Christian

Published in:

Journal of Agricultural and Food Chemistry

Link to article, DOI:

10.1021/acs.jafc.9b01529

Publication date:

2019

Document Version

Peer reviewed version

Link back to DTU Orbit

Citation (APA):

Shen, J., Chen, J., Jensen, P. R., \& Solem, C. (2019). Sweet As Sugar-Efficient Conversion of Lactose into Sweet Sugars Using a Novel Whole-Cell Catalyst. Journal of Agricultural and Food Chemistry, 67(22), 62576262. https://doi.org/10.1021/acs.jafc.9b01529

\section{General rights}

Copyright and moral rights for the publications made accessible in the public portal are retained by the authors and/or other copyright owners and it is a condition of accessing publications that users recognise and abide by the legal requirements associated with these rights.

- Users may download and print one copy of any publication from the public portal for the purpose of private study or research.

- You may not further distribute the material or use it for any profit-making activity or commercial gain

- You may freely distribute the URL identifying the publication in the public portal 
1 Sweet as Sugar - Efficient conversion of lactose into sweet sugars using a novel whole-cell-

2 catalyst

3

4

5 Jing Shen ${ }^{1}$, Jun Chen ${ }^{1}$, Peter Ruhdal Jensen ${ }^{1 *}$ and Christian Solem ${ }^{1 *}$

61 National Food Institute, Technical University of Denmark, 2800 Kongens Lyngby, Denmark

$7 \quad$ *Peter Ruhdal Jensen: Tel, +45 45252510, E-mail, perj@food.dtu.dk;

$8 \quad *$ Christian Solem: Tel, +45 30585533, E-mail, chso@food.dtu.dk

9

10

11

12

13

14

15

16

17

18 
20 Abstract

21 Lactose, the sugar contained in milk, has a low sweetness. We have constructed an efficient whole-

22 cell catalyst (WCC), that can be grown on dairy waste and which is able to convert lactose into a

23 mixture of sugars as sweet as sucrose. The WCC is based on Corynebacterium glutamicum

24 ATCC13032, which has been engineered to metabolize lactose, to express xylose and arabinose

25 isomerase and to eliminate byproduct formation. When introduced in concentrated cheese whey

26 permeate, its content of $98 \mathrm{~g} / \mathrm{L}$ lactose was completely hydrolyzed and the liberated sugars partially

27 isomerized into $23.5 \mathrm{~g} / \mathrm{L}$ fructose and $20.4 \mathrm{~g} / \mathrm{L}$ tagatose, which corresponds to a $49 \%$ conversion of

28 the glucose and a $44 \%$ conversion of galactose. The latter is similar to what can be obtained using

29 purified enzymes. The new technology enables better resource utilization and allows for dairy waste

30 to be converted into a valuable food sweetener with many potential uses.

31 Keywords: whole-cell catalyst, Corynebacterium glutamicum, lactose hydrolysis, sugar

32 isomerization, sweetener 


\section{Introduction}

Lactose, a disaccharide consisting of one glucose molecule joined to a galactose molecule by a ß-1, 4-glycosidic linkage, is the primary sugar found in the milk of mammals. Lactose first emerged as a commercial commodity during the $18^{\text {th }}$ century ${ }^{1}$, and with the later expansion of the dairy industry increasing volumes of various lactose-containing (waste) streams followed. Whey and whey permeate are examples of such streams that are generated from manufacture of cheese and other fermented dairy products. The amount of lactose anually produced in the form of dried whey is estimated to be more than $1,400,000$ tons $^{2}$.

Whey permeate, or deproteinized whey, has several applications within the food and confectionery industry, where it promotes sweetness and adds flavor to the product ${ }^{1}$. Beyond food applications, lactose is also used by the pharmaceutical industry as a bulking agent ${ }^{3}$. With the explosive rise in cheese production since the latter half of the $20^{\text {th }}$ century, an urgent need for new alternative ways to utilize whey has arisen. Two types of use have gained most attention, where the first is microbial conversion of lactose into different value added compounds ${ }^{4,5}$, and the second involves hydrolysis of lactose into glucose and galactose that can be used for sweetening purposes .

Lactose has a low sweetness (16\% of the Perceived Swweetness of Sucrose, PSS) compared to its monosaccharide moieties, glucose (74\% PSS) and galactose (32\% PSS) ${ }^{6}$. Hydrolysis of lactose into the glucose/galactose syrup extends the use of whey permeate as a sweetening agent, not only because the syrup is three times sweeter than lactose ${ }^{7}$, but also because $70 \%$ of the world's population suffer from lactose intolerance, due to an inability to metabolize lactose ${ }^{8}$.

Chemical hydrolysis of lactose requires harsh conditions such as very high temperatures (up to $\left.150^{\circ} \mathrm{C}\right)$ and extremely acidic conditions $(\mathrm{pH}<1.5)$, which result in formation of undesirable byproducts ${ }^{9}$ and hydrolysis using enzymes is thus the preferred choice. Enzymatic hydrolysis of 
63 lactose is a quite common procedure, and is typically carried out at temperatures between $30^{\circ} \mathrm{C}$ and

$6450^{\circ} \mathrm{C}^{10}$. The purified beta-galactosidase are normally derived from various microbes, either natural

65 or recombinant ${ }^{11}$.

Although hydrolysis of lactose increases sweetness, the liberated glucose and galactose are not excessively sweet, and, in particular, galactose has a low sweetness. It is possible to isomerize glucose into fructose and galactose into tagatose by using enzymes, and thereby not only increase the overall sweetness but also reduce the glycemic index, which is desirable for food applications ${ }^{12}$. As for lactose hydrolysis, isomerization using purified microbial enzymes is preferred before the use of chemical catalysts, as the conditions are milder and the process less sophisticated ${ }^{13,14}$. Since the 1970s, high-fructose corn sirup (HFCS) has been used as a sweetener in foods and soft drinks and the market for HFCS is immense ${ }^{15}$. Tagatose came on the market later, however, is also considered a promising sugar substitute due to its high-sweetness (92\% to sucrose) and low-calorie features ${ }^{16}$.

Whole-cell catalysis is not a novel approach, and in the past few decades, WCC have been used to produce a wide variety of products in various industries ${ }^{17,18}$. Whole-cell catalysis potentially has several advantages over the use of purified enzymes ${ }^{18}$. First, there is no need for a costly enzyme purification step ${ }^{18}$. Second, the protected intracellular environment stabilizes enzymes under harsh conditions. Third, for re-use, whole cells can easily be recovered by simple filtration or the cells can be immobilized ${ }^{19}$.

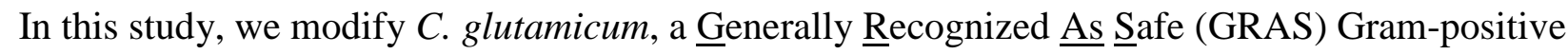
bacterium to become a host for expressing the relevant enzymes needed for lactose hydrolysis and subsequent isomerization. The strain applied is able to ferment lactose, and lacks lactate dehydrogenase. We demonstrate that this engineered C. glutamicum strain efficiently can convert 
whey permeate into a sweet syrup in a single-step process.

\section{Methods}

\section{Growth medium and conditions.}

Escherichia coli (E. coli) strains were grown aerobically in Luria-Bertani broth (LB) ${ }^{20}$ at $37^{\circ} \mathrm{C}$, and C. glutamicum strains were cultivated in Brain Heart Infusion broth (BHI) or CGXII minimal medium at $30^{\circ} \mathrm{C}$ with 200 -rpm shaking ${ }^{21}$. When appropriate, kanamycin was added to a concentration of $50 \mu \mathrm{g} / \mathrm{mL}$ for E. coli and $25 \mu \mathrm{g} / \mathrm{mL}$ for C. glutamicum, and chloramphenicol was used at a concentration of $25 \mu \mathrm{g} / \mathrm{mL}$ for $E$. coli and $8 \mu \mathrm{g} / \mathrm{mL}$ for $C$. glutamicum. When needed, one mM of IPTG (isopropyl $\beta$-D-1-thiogalactopyranoside) was added to induce gene expression.

\section{Deletion of the IdhA gene in C. glutamicum.}

Preparation of electrocompetent $C$. glutamicum cells as well as transformation were carried out as described previously ${ }^{22}$. The deletion of the IdhA gene in JS95 ${ }^{23}$ was conducted via a two-step homologous recombination procedure using the vector pK18mobsacB ${ }^{24}$. Briefly, two 800-bp downstream and upstream gBlock fragments of IdhA were ordered from Integrated DNA Technologies (Coralville, IA, U.S.) and cloned into the multiple cloning site of pK18mobsacB with the Gibson cloning kit (SGI-DNA, La Jolla, CA, U.S. ). The resulting plasmids were transformed into the electrocompetent JS95, and clones with the plasmid successfully integrated were selected on BHI plates with kanamycin. Counter-selection was performed on BHI with 10\% sucrose. Successful IdhA knockouts were confirmed by Sanger sequencing, and strain JS99 is one of these.

\section{Plasmid-based expression of xylose isomerase and arabinose isomerase (construct A).}

The xylA gene from Arthrobacter sp. NRRL B3728 ${ }^{25}$ encoding xylose isomerase and the araA gene from Bacillus coagulans NL01 ${ }^{26}$ encoding arabinose isomerase were chosen for the purpose of 
isomerizing glucose into fructose and galactose into tagatose respectively. Two gBlock gene fragments were ordered from Integrated DNA Technologies (Coralville, IA, U.S.) and assembled with the $X b a I$ digested vector pEC-XC99E ${ }^{27}$. The ligation mix was first electroporated into the $E$. coli TOP10 cells. Colonies with correct construct (construct A, Figure S1) were verified by colony PCR and followed by Sanger sequencing. The plasmids were subsequently isolated from E. coli using the Zyppy Plasmid Miniprep Kit (Irvine, CA, U.S.) and electroporated into the C. glutamicum competent cells.

\section{Plasmid-based expression of xylose isomerase and arabinose isomerase using tandem repetitive promoters (construct $B$ )}

The shuttle plasmid pEC-XC99E for C. glutamicum was used as the backbone for the construction of the new expression vector. First, two gBlock gene fragments (Integrated DNA Technologies, Coralville, IA, U.S.), each of which contained a $\operatorname{trc}$ promoter sequence, were assembled into the BamHI site of pEC-XC99E using the Gibson cloning kit (SGI-DNA, La Jolla, CA, U.S.) resulting in the plasmid pJS150. Afterwards, two additional trc promoter sequences were introduced into the SalI site of pJS150 with the same cloning strategy and generated a new SalI site at the 3' of the promoter sequence. The final vector, pJS151, contained four additional trc promoters downstream of the original promoter in pEC-XC99E. The xylA and araA genes were cloned into the new SalI site of pJS151 to generate the construct B.

\section{Construction of the expression plasmid with lacZ (construct C).}

The lacZ gene was PCR amplified from the genomic DNA of Streptococcus thermophilus (S. thermophilus) with the following primers placZ-F:

ACCTCCTGGGCTCCCGCTAATCGACCTGCAGTTATTACCTTCAAAAAAGG and placZR:CATCCGCCAAAACAGCCAAGCTTGCATGCCCTAATTTAGTGGTTCAATCA. The 
fragment was cloned into the pstI site downstream the xylA and $\operatorname{araA}$ gene in the construct $\mathrm{B}$ with the Gibson cloning (SGI-DNA, La Jolla, CA, U.S.) to generate construct C.

\section{Sugar hydrolysis and isomerization.}

One mL of overnight culture of the cell catalyst in BHI medium was inoculated in 50-ml CGXII supplied with 5\% lactose and 1mM IPTG. After 24 hours of cultivation, the cells were harvested by centrifugation (5,000 g for 10 minutes). The pellet was washed once with $0.9 \% \mathrm{NaCl}$ solution. For the hydrolysis of lactose and further isomerization, 15 g/L DCW (dry cell weight) cells were resuspended in $40 \mathrm{mM}$ MOPS solution $(\mathrm{pH}=7.5)$ containing lactose, and incubated under static conditions at $60^{\circ} \mathrm{C}$. For the hydrolysis of the whey lactose, the $\mathrm{pH}$ of ultra-filtrated cheese whey was adjusted to $\mathrm{pH} 7.5$ prior to the use for the whole-cell catalysis. The concentration of cells and other reaction settings used in whey was same as that used in lactose MOPS solution.

\section{Thermal stability test for $\beta$-galactosidase, xylose isomerase and tagatose isomerase.}

The thermal stability of $\beta$-galactosidase and isomerases was monitored after incubation of the WCC in whey permeate under static conditions at $60^{\circ} \mathrm{C}$. The WCC was sampled at periodic intervals for the measurement of the residual activity in $40 \mathrm{mM}$ MOPS solution $(\mathrm{pH}=7.5)$ with either $50 \mathrm{~g} / \mathrm{L}$ lactose, glucose or galactose. The activities at 0 hour were defined as $100 \%$.

\section{HPLC analysis of sugars and acids.}

The concentration of lactate was determined on an Ultimate 3000 high-performance liquid chromatography system (Dionex) equipped with an Aminex HPX-87H column (Bio-Rad) and a Shodex RI-101 detector (Showa Denko K.K.). The column oven temperature was set to $60^{\circ} \mathrm{C}$ and the mobile phase consisted of $5 \mathrm{mM} \mathrm{H}_{2} \mathrm{SO}_{4}$. The flow rate used was $0.5 \mathrm{~mL} / \mathrm{min}^{28}$. For the 
measurement of lactose, glucose, galactose, fructose and tagatose (Sigma-Aldrich), the same system and setup were used, except for the column (Agilent Hi-Plex Ca column) and mobile phase (water).

\section{Results \& Discussion}

\section{C. glutamicum retains a low glycolytic activity at $60^{\circ} \mathrm{C}$}

Previously we have engineered C. glutamicum into efficiently metabolizing lactose, by introducing the lactose permease and the $\beta$-galactosidase from Streptococcus thermophilus and the Leloir pathway from Lactococcus lactis on the chromosome ${ }^{23}$. C. glutamicum readily grows under aerated conditions, but not when deprived of oxygen. We hypothesized that the engineered strain, JS95, when incubated at elevated temperatures could serve as a whole-cell catalyst for hydrolyzing lactose due to heat-induced permeabilization of its membrane, and tested this. Using $15 \mathrm{~g} / \mathrm{L} \mathrm{DCW}$ cells, $114.20 \mathrm{~g} / \mathrm{L}$ lactose could be completely hydrolyzed within 24 hours at $60^{\circ} \mathrm{C}$, and a total of $108.13 \mathrm{~g} / \mathrm{L}$ glucose and galactose were generated (Table 1 ). The sugar recovery rate reached 94.68\%. Besides the glucose and galactose, we found that lactate had been formed in small amounts (3.05 g/L). C. glutamicum is an aerobic bacterium that ceases to grow under anaerobic conditions, however, it retains the ability to metabolize sugars into organic acids, mainly lactate, due to an active glycolysis and lactate dehydrogenase ${ }^{29}$. We expected that the high temperature incubation would inactivate central metabolism in the mesophilic C. glutamicum, however, lactate formation indicated that this was not the case. Previously it has been reported for some mesophiles, with a high abundance of glycolytic enzymes, that some residual activity persists for a period after high temperature exposure ${ }^{30}$. Howell et al. demonstrated that most glycolytic enzymes in mesophilic bacteria still maintained $50 \%$ activity after a half-hour heat treatment at $55^{\circ} \mathrm{C}-70^{\circ} \mathrm{C}{ }^{31}$. To eliminate lactate formation, we decided to delete the $I d h A$ gene, which is solely responsible for the formation of lactate in C. glutamicum ${ }^{32}$. Indeed after deleting $l d h A$, lactate formation ceased, and 
the sugar recovery rate increased to $97.21 \%$ compared to $94.68 \%$ with the reference strain JS95 (Table 1). The IdhA-null strain JS99 appeared to be an ideal starting point for further engineering.

\section{Concurrent hydrolysis of lactose and isomerization of its constituent monosaccharides by} using recombinant $C$. glutamicum-based cell catalysts.

To isomerize glucose and galactose into fructose and tagatose respectively, we decided to rely on the promiscuous activities of xylose isomerase (fructose isomerase) and arabinose isomerase (tagatose isomerase). First, we introduced xylA gene from Arthrobacter sp. NRRL B3728 ${ }^{25}$ and araA gene from Bacillus coagulans strain $\mathrm{NL}^{2} 1^{26}$ in strain JS99, by using the plasmid pEC-XC99E as expression vector (construct A), and obtained strain JS154. After a 72-h static incubation with 15 g/L DCW cells of JS154 at $60^{\circ} \mathrm{C}, 95 \mathrm{~g} / \mathrm{L}$ lactose could be hydrolyzed and converted into a mixture of $23.0 \pm 0.5 \mathrm{~g} / \mathrm{L}$ glucose, $22.8 \pm 0.2 \mathrm{~g} / \mathrm{L}$ fructose, $32.7 \pm 0.9 \mathrm{~g} / \mathrm{L}$ galactose, and $12.8 \pm 0.4 \mathrm{~g} / \mathrm{L}$ tagatose. In this process, the high temperature exposure created a leaky cell envelope, through which the substrate could enter and the products could leave. The conversion was efficient and only small amounts of lactose remained $(0.8 \pm 0.0 \mathrm{~g} / \mathrm{L})$. The amount of glucose and galactose converted into fructose and tagatose were $50 \%$ and $28 \%$ respectively. In a comparable study ${ }^{26}$, where the araA gene from Bacillus coagulans strain NL01 was expressed in E. coli, the amount of galactose converted into tagatose reached a maximum of $40 \%$ when applying whole-cell catalysis with galactose as the substrate. The lower sugar isomerization efficiency achieved in our setting indicated that there was room for improvement. It is possible that the araA gene was expressed less well in C. glutamicum than in E. coli, e.g. because of differences in transcription/translation efficiency or because of differences in copy-number of the plasmid used for expressing araA. For $E$. coli, high copy-number expression vectors and strong inducible promoters are widely available, but this is hardly the case for $C$. glutamicum ${ }^{33}$. Second, the fact that we had integrated the $\beta$ galactosidase in the chromosome, could have generated a bottleneck for subsequent isomerization. 
It is possible that lactose hydrolysis was a rate-limiting step which potentially could exacerbate the effect due to loss of activity of the xylose isomerase and arabinose isomerase at high temperatures

${ }^{26}$. For all of these reasons, we attempted to improve the expression of the three genes.

\section{Optimization of isomerization efficiency by increasing gene expression.}

In order for whole-cell catalysts to be efficient, it is essential that the relevant enzymes are expressed to a sufficiently high level ${ }^{18}$. Most of the expression vectors for C. glutamicum rely on the tac/trc promoters, and although these promoters are derived from E. coli, they provide inducible high-level expression of target genes in $C$. glutamicum ${ }^{34}$. However, the copy number of $C$. glutamicum vectors is generally low ( 20 copies per cell), and this could be a limiting factor for overall expression. Shin et al. compared the influence of different media on the level of heterologous protein expression in C. glutamicum, and found that Riesenberg broth supported the highest expression levels when compared to other commonly used media such as BHI and CGXII ${ }^{19}$. However, the use of a specific medium could restrict industrial applications, as industrial media often contain many complex components. When we used construct A, the conversion of galactose into tagatose was merely $12 \%$ lower than that obtained in the previous study using E. coli. To avoid the risk of overloading cellular metabolism by using high copy number expression vectors, we decided to introduce multiple trc promoters upstream of the genes in the vector pEC-XC99E, which appeared to be a fast and controllable manner in which the expression could be increased ${ }^{35}$.

Four additional trc promoters were introduced and in the new construct (B), the xylA and araA genes were transcribed from five tandem trc promoters (Figure S1). The strain JS99 with construct B was designated JS155. When the isomerization was performed with JS155, an increase in productivity of approximately $60 \%$ and $120 \%$ for fructose and tagatose respectively was observed (Figure 1\& 2B), and the tagatose titer increased from $12.8 \mathrm{~g} / \mathrm{L}$ to $19.4 \mathrm{~g} / \mathrm{L}$. With the new construct 

demonstrates that the expression level was the limiting factor. The final fructose titer did not change, however, this was not expected as a $50 \%$ conversion corresponds to the equilibrium between galactose and tagatose at $60^{\circ} \mathrm{C}^{12}$. Therefore, with a higher xylA expression, only the maximum productivity could be improved, and not the conversion ratio. The xylose isomerase used in this study is a thermally stable enzyme ${ }^{12}$, and the partial thermal denaturation taking place during the isomerization process $\left(72 \mathrm{~h}\right.$ at $60^{\circ} \mathrm{C}$ ) apparently was not significant as equilibrium could be reached. This was clearly not the case for arabinose isomerase, where complete loss of activity was observed before equilibrium could be reached (Figure 2).

Only one copy of the lacZ gene was present in the chromosome of strain JS99, in contrast to the xylA and araA genes, that both were expressed on plasmids from strong promoters. The relatively low intracellular level of $\beta$-galactosidase probably limited the maximum productivity of fructose and tagatose, due to a slow release of glucose and galactose. To overcome this potential limitation, we made a new construct $\mathrm{C}$, by inserting an additional lacZ gene downstream of the xylA and araA genes in construct B (Figure S1). Strain JS99 carrying construct C was designated JS156. This final catalyst was able to completely hydrolyze lactose within 12 hours, as compared to 24 hours for the catalyst based on construct B (Figure 3) (the construct B). With construct C, both the maximum production rates of fructose and tagatose were further improved by $45 \%$ and $50 \%$ compared to construct B on lactose respectively. As expected, the increased cleavage rate of lactose did not improve the conversion into fructose and tagatose, as the equilibrium between glucose/fructose and galactose/tagatose at $60^{\circ} \mathrm{C}$ had been reached ${ }^{12,26}$.

\section{Simultaneous whey lactose hydrolysis and isomerization of glucose and galactose}

Eventually, we applied the cell catalyst JS156 on concentrated cheese whey permeate. The cheese 
whey ultra-filtrated permeates contained approximately $98 \mathrm{~g} / \mathrm{L}$ lactose. With the incubation of 15 g/L DCW JS156 cells at $60^{\circ} \mathrm{C}$ for 48 hours, the final whey-based GGFT syrup was composed of $24.3 \pm 0.0 \mathrm{~g} / \mathrm{L}$ glucose, $25.7 \pm 0.1 \mathrm{~g} / \mathrm{L}$ galactose, $23.5 \pm 0.3 \mathrm{~g} / \mathrm{L}$ fructose and $20.4 \pm 0.1 \mathrm{~g} / \mathrm{L}$ tagatose. A high thermostability is a desired property for a catalyst to be applied at elevated temperatures, and we therefore examined the stability of the three enzyme activities over time at $60^{\circ} \mathrm{C}$. It was found (Figure S2) that the activity of the two isomerases remained high and unaffected started to reduce after 12 hours, but prior to this, the lactose had been completely hydrolyzed (Figure 3).

In recent years, tagatose, as a GRAS food additive, has been extensively researched as a functional sweetener $^{36}$. Several researches on tagatose production from lactose or lactose-containing feedstock have been reported. Xu et al. reported a single-step process for tagatose production from lactose based on recombinant $E$. coli whole cells expressing an arabinose isomerase from Lactobacillus fermentum CGMCC2921 and a $\beta$-galactosidase from Thermus thermophiles HB27, where a maximum yield of $20.2 \%$ tagatose could be reached ${ }^{37}$. To improve the productivity and yield, cell permeabilization and immobilization usually is carried out. Jayamuthunagai et al. produced tagatose from lactose in whey permeate by using a combination of enzyme treatment (beta-galactosidase) and alginate immobilized Lactobacillus plantarum cells (arabinose isomerase), and achieved a conversion of $38 \%^{38}$, but the research only focused on conversion of the galactose moiety of lactose without considering to the possibility of generating sweetness from glucose. Rhimi et al. have previously reported that it is possible to produce tagatose and fructose from a mixture of galactose and glucose using an E. coli WCC expressing arabinose isomerase and xylose isomerase ${ }^{39}$. Rhimi et al. used a mixture of glucose and galactose in MOPS buffer and a WCC that had been grown in LB medium, a setup that is quite far from real-life applications. Even though Torres et al. ${ }^{40}$ reported the 
use of an immobilized tri-enzymatic system composed of $\beta$-galactosidase, xylose isomerase and arabinose isomerase for bioconversion of lactose, simultaneous hydrolysis of lactose and isomerization of the released sugars using a whole cell catalyst has not been reported. Torres et al. found that lactose hydrolysis was incomplete in all their experiments employing tri-enzymatic system because of product inhibition by galactose and glucose ${ }^{40}$. When we employed our whole-cell catalyst in whey permeate, not only did we achieve complete lactose hydrolysis, but also efficient isomerization of glucose and galactose. There was no residual lactose, a $49 \%$ conversion of the glucose into fructose and a $44 \%$ conversion of the galactose into tagatose, which is comparable to what can be achieve using purified enzymes.

In a one-step process, the sweetness of whey was increased by $440 \%$ and $160 \%$ compared to the untreated whey and whey that merely had been hydrolyzed into glucose and galactose, respectively (Figure 4). The conversion was associated with a decrease in glycemic index by 25\%, when compared to untreated whey (Figure 4). The results clearly show that microbial catalysis is an efficient approach for turning cheese whey into a value-added sweetener, with potential benefits to human health.

In conclusion, we have presented a novel approach for valorizing cheese whey permeate, a low- or negative value side stream generated in enormous amounts by the dairy industry. By co-expressing $\beta$-galactosidase, xylose isomerase and arabinose isomerase in C. glutamicum, a cell catalyst was made that efficiently could convert whey lactose into a sweet GGFT syrup, with lower calorie content and glycemic index. It is well-established that a high sugar consumption can cause various lifestyle-diseases such as obesity and type 2 diabetes ${ }^{41}$ and there have been several initiatives from organizations (FAO/WHO) and health authorities aiming at lowering the consumption of sugar. The technology developed addresses these societal challenges, while at the same time supporting a better resource utilization at dairies. The generation of the C. glutamicum cell catalyst is also cost- 
293 effective, since we previously have demonstrated that the host strain can grow on whey permeate 294 without addition of expensive nutrients. We believe that it is possible to optimize the performance 295 of the cell catalyst, e.g. by making the cells more permeable. To increase stability and to facilitate 296 reuse, immobilization approaches could be tested.

297

298 Author Information

299 Corresponding Authors

300 *PRJ. Tel: +45 45252510, E-mail: perj@food.dtu.dk;

$301 *$ *S. Tel: +45 30585533, E-mail: chso@food.dtu.dk.

302 ORCID

303 Peter Ruhdal Jensen: 0000-0003-2080-2070;

304 Christian Solem: 0000-0002-3898-280X.

$305 \quad$ Funding

306 This work was supported by the Bio-Value Strategic Platform for Innovation and Research which is 307 co-funded by The Danish Council for Strategic Research and The Danish Council for Technology 308 and Innovation, grant no: 0603-00522B.

309 Notes

310 The authors declare no competing financial interest.

\section{Supporting Information Statement}


The Supporting Information is available free of charge on the ACS Publications website.

313 Figure S1. The plasmid maps of different constructs used in the study. The xylA gene sequence. The 314 araA gene sequence. Two gBlocks containing trc promoter sequence.

\section{References}

318 (1) Gänzle, M. G.; Haase, G.; Jelen, P. Lactose: Crystallization, Hydrolysis and Value-Added 319 Derivatives. Int. Dairy J. 2008, 18 (7), 685-694. https://doi.org/10.1016/j.idairyj.2008.03.003.

(2) IDF. World Dairy Situation. Bulletin 399.; Brussels, 2005.

(3) EMEA. Risk and Regulatory Assessment of Lactose and Other Products Prepared for Using Calf Rennet; London, 2002.

(4) Porro, D.; Martegani, E.; Ranzi, B. M.; Alberghina, L. Lactose/Whey Utilization and Ethanol Production by Transformed Saccharomyces Cerevisiae Cells. Biotechnol. Bioeng. 1992, 39

327 (5) Guimarães, P. M. R.; Teixeira, J. A.; Domingues, L. Fermentation of Lactose to Bio-Ethanol by Yeasts as Part of Integrated Solutions for the Valorisation of Cheese Whey. Biotechnol. (8), 799-805. https://doi.org/10.1002/bit.260390802. Adv. 2010, 28 (3), 375-384. https://doi.org/10.1016/j.biotechadv.2010.02.002.

(6) Joesten, M. D.; Hogg, J. L.; Castellion, M. E. The World of Chemistry: Essentials: Essentials; Cengage Learning, 2006. 
332 (7) Fox, P. F.; McSweeney, P. L. H. Dairy Chemistry and Biochemistry. 1998.

333 (8) Heyman, M. B. Lactose Intolerance in Infants, Children, and Adolescents. Pediatrics 2006, 334

(12) Bhosale, S. H.; Rao, M. B.; Deshpande, V. V. Molecular and Industrial Aspects of Glucose Isomerase. Microbiol. Rev. 1996, 60 (2), 280-300.

(13) Li, H.; Yang, S.; Saravanamurugan, S.; Riisager, A. Glucose Isomerization by Enzymes and Chemo-Catalysts: Status and Current Advances. ACS Catal. 2017, 7 (4), 3010-3029. https://doi.org/10.1021/acscatal.6b03625.

(14) Kim, P. Current Studies on Biological Tagatose Production Using L-Arabinose Isomerase: A Review and Future Perspective. Appl. Microbiol. Biotechnol. 2004, 65 (3), 243-249. https://doi.org/10.1007/s00253-004-1665-8.

(15) Parker, K.; Salas, M.; Nwosu, V. C. High Fructose Corn Syrup : Production, Uses and Public Health Concerns. Biotechnol. Mol. Biol. Rev. 2010, 5(5) (December), 71-78. https://doi.org/10.1080/17441692.2012.736257. 
(16) Levin, G. V. Tagatose, the New GRAS Sweetener and Health Product. J. Med. Food 2002, 5 (1), 23-36. https://doi.org/10.1089/109662002753723197.

(17) Wachtmeister, J.; Rother, D. Recent Advances in Whole Cell Biocatalysis Techniques Bridging from Investigative to Industrial Scale. Curr. Opin. Biotechnol. 2016, 42, 169-177. https://doi.org/10.1016/j.copbio.2016.05.005.

(18) Lin, B.; Tao, Y. Whole-Cell Biocatalysts by Design. Microb. Cell Fact. 2017, 16 (1), 1-12. https://doi.org/10.1186/s12934-017-0724-7.

(19) Shin, K.-C.; Sim, D.-H.; Seo, M.-J.; Oh, D.-K. Increased Production of Food-Grade dTagatose from d-Galactose by Permeabilized and Immobilized Cells of Corynebacterium Glutamicum, a GRAS Host, Expressing d-Galactose Isomerase from Geobacillus Thermodenitrificans. J. Agric. Food Chem. 2016, 64 (43), 8146-8153. https://doi.org/10.1021/acs.jafc.6b03588.

(20) Sambrook, J.; Fritsch, E. F.; Maniatis, T. Molecular Cloning: A Laboratory Manual. Cold Spring Harbor Laboratory Press; 1989.

(21) Eggeling, L.; Bott, M. Handbook of Corynebacterium Glutamicum; Eggeling, L., Bott, M., Eds.; CRC Press: Boca Raton, 2005. https://doi.org/10.1201/9781420039696.

(22) Shen, J.; Chen, J.; Jensen, P. R.; Solem, C. A Novel Genetic Tool for Metabolic Optimization of Corynebacterium Glutamicum: Efficient and Repetitive Chromosomal Integration of Synthetic Promoter-Driven Expression Libraries. Appl. Microbiol. Biotechnol. 2017, 101 (11), 4737-4746. https://doi.org/10.1007/s00253-017-8222-8. 
(23) Shen, J.; Chen, J.; Jensen, P. R.; Solem, C. Development of a Novel, Robust and CostEfficient Process for Valorizing Dairy Waste Exemplified by Ethanol Production. Microb. Cell Fact. 2019, 18 (1), 1-10. https://doi.org/10.1186/s12934-019-1091-3.

(24) Schäfer, a; Tauch, a; Jäger, W.; Kalinowski, J.; Thierbach, G.; Pühler, a. Small Mobilizable Multi-Purpose Cloning Vectors Derived from the Escherichia Coli Plasmids PK18 and PK19: Selection of Defined Deletions in the Chromosome of Corynebacterium Glutamicum. Gene 1994, 145 (1), 69-73.

(25) Loviny-Anderton, T.; Shaw, P. C.; Shin, M. K.; Hartley, B. S. D-Xylose (D-Glucose) Isomerase from Arthrobacter Strain N.R.R.L. B3728. Gene Cloning, Sequence and Expression. Biochem. J. 1991, 277 ( Pt 1, 263-271.

(26) Mei, W.; Wang, L.; Zang, Y.; Zheng, Z.; Ouyang, J. Characterization of an L-Arabinose Isomerase from Bacillus Coagulans NL01 and Its Application for D-Tagatose Production. BMC Biotechnol. 2016, 16 (1), 1-11. https://doi.org/10.1186/s12896-016-0286-5.

(27) Kirchner, O.; Tauch, A. Tools for Genetic Engineering in the Amino Acid-Producing Bacterium Corynebacterium Glutamicum. J. Biotechnol. 2003, 104 (1-3), 287-299. https://doi.org/10.1016/S0168-1656(03)00148-2.

(28) Chen, J.; Shen, J.; Ingvar Hellgren, L.; Ruhdal Jensen, P.; Solem, C.; Hellgren, L. I.; Jensen, P. R.; Solem, C. Adaptation of Lactococcus Lactis to High Growth Temperature Leads to a Dramatic Increase in Acidification Rate. Sci. Rep. 2015, 5, 14199. https://doi.org/10.1038/srep14199. 
(29) Ica, B.; Ucts, P.; Pro, N. D.; Engine, C.; Okino, S.; Inui, M.; Yukawa, H. Production of Organic Acids by Corynebacterium Glutamicum under Oxygen Deprivation. Appl. Microbiol. Biotechnol. 2005, 475-480. https://doi.org/10.1007/s00253-005-1900-y.

(30) Voges, R.; Corsten, S.; Wiechert, W.; Noack, S. Absolute Quantification of Corynebacterium Glutamicum Glycolytic and Anaplerotic Enzymes by QconCAT. J. Proteomics 2015, 113, 366-377. https://doi.org/10.1016/j.jprot.2014.10.008.

(31) Howell, N.; Akagi, J. M.; Himes, R. H. Thermostability of Glycolytic Enzymes from Thermophilic Clostridia. Can. J. Microbiol. 1969, 15 (5), 461-464.

(32) Inui, M.; Murakami, S.; Okino, S.; Kawaguchi, H.; Vertès, A. a; Yukawa, H. Metabolic Analysis of Corynebacterium Glutamicum during Lactate and Succinate Productions under Oxygen Deprivation Conditions. J. Mol. Microbiol. Biotechnol. 2004, 7 (4), 182-196. https://doi.org/10.1159/000079827.

(33) Patek, M. and P. V. of C. glutamicum; Nesvera, J. Promoters and Plasmid Vectors of Corynebacterium Glutamicum. In Corynebacterium glutamicum: Biology and Biotechnology; Yukawa, H., Inui, M., Eds.; Berlin Heidelberg, 2013; Vol. 23. https://doi.org/10.1007/978-3642-29857-8.

(34) Nesvera, Jan; Patek, M. Plasmids and Promoters in Corynebacteria and Their Applications. Corynebacteria Genomics Mol. Biol. 2008, 113-154.

(35) A strategy of gene overexpression based on tandem repetitive promoters in Escherichia coliLi, M.; Wang, J.; Geng, Y.; Li, Y.; Wang, Q.; Liang, Q.; Qi, Q. A Strategy of Gene Overexpression Based on Tandem Repetitive Promoters in Escherichia Coli. Microb. Cell Fact. 2012, 11, 1-10. https://doi.org/10.1186/1475-2859-11-19. 
415 (36) Tandel, K. Sugar Substitutes: Health Controversy over Perceived Benefits. J. Pharmacol. Pharmacother. 2011, 2 (4), 236. https://doi.org/10.4103/0976-500x.85936.

(37) Xu, Z.; Xu, Z.; Tang, B.; Li, S.; Gao, J.; Chi, B.; Xu, H. Construction and Co-Expression of Polycistronic Plasmids Encoding Thermophilic l-Arabinose Isomerase and Hyperthermophilic $\beta$-Galactosidase for Single-Step Production of d-Tagatose. Biochem. Eng.

(38) Jayamuthunagai, J.; Srisowmeya, G.; Chakravarthy, M.; Gautam, P. D-Tagatose Production by Permeabilized and Immobilized Lactobacillus Plantarum Using Whey Permeate.

(39) Rhimi, M.; Messaoud, E. Ben; Borgi, M. A.; khadra, K. Ben; Bejar, S. Co-Expression of lArabinose Isomerase and d-Glucose Isomerase in E. Coli and Development of an Efficient Process Producing Simultaneously d-Tagatose and d-Fructose. Enzyme Microb. Technol. 2007, 40 (6), 1531-1537. https://doi.org/10.1016/j.enzmictec.2006.10.032.

(40) Torres, P.; Batista-Viera, F. Immobilized Trienzymatic System with Enhanced Stabilization for the Biotransformation of Lactose. Molecules 2017, 22 (2). https://doi.org/10.3390/molecules22020284.

(41) Herman, W. H.; Ye, W.; Griffin, S. J.; Simmons, R. K.; Davies, M. J.; Khunti, K.; Rutten, G. E. H. M.; Sandbaek, A.; Lauritzen, T.; Borch-Johnsen, K.; et al. Early Detection and Treatment of Type 2 Diabetes Reduce Cardiovascular Morbidity and Mortality: A Simulation of the Results of the Anglo-Danish-Dutch Study of Intensive Treatment in People with Screen-Detected Diabetes in Primary Care (ADDITION-Europe). Diabetes Care 2015, 38 (8), 1449-1455. https://doi.org/10.2337/dc14-2459. 
438 Figure 1. Comparison of fructose and tagatose formation from lactose using JS154 and JS155.

439 JS154: JS99 harboring construct A, where the isomerase genes ( $x y l A$, araA) are expressed from the 440 tac promoter in pEC-XC99E; JS155: JS99 harboring construct B, where the isomerase genes are 441 expressed from multiple tandem promoters inserted upstream the tac promoter in pEC-XC99E. The 442 schematic of the plasmids used can be seen in Figure S1.

443 Figure 2. Comparison of productivity and conversion ratio for different cell catalysts. A, fraction of 444 glucose and galactose converted into fructose and tagatose; $\mathrm{B}$, the maximum productivity of 445 fructose and tagatose during the one-step lactose conversion. JS154: JS99 harboring construct A, 446 where xylA and $a r a B$ are co-expressed on pEC-XC99E; JS155: JS99 harboring construct B, where $447 \quad x y l A$ and $a r a B$ are co-expressed on pEC-XC99E from four additional trc promoters; JS156: JS99 448 harboring construct C, where xylA, araB and lacZ were co-expressed on pEC-XC99E from four 449 additional trc promoters (plasmid maps can be seen in Figure S1).

450 Figure 3. Comparison of lactose hydrolysis rate with JS155 and JS156. JS155: only one copy of 451 lacZ on the chromosome of JS99. JS156: additional lacZ were co-expressed on pEC-XC99E from 452 four additional trc promoters in JS99 (The illustration of plasmid maps can be seen in Figure S1).

453 Figure 4. Comparison of relative sweetness and glycemic index between raw whey and enzyme454 treated whey. Lactose-hydrolyzed whey, treated with JS99; Sugar-isomerized whey, treated with 455 JS156 which is JS99 bearing the construct C. 
Table 1

\begin{tabular}{llll}
\hline Strain & Glu + Gal (g/L) & Lactate $(\mathbf{g} / \mathbf{L})$ & Sugar Recovery $(\%)$ \\
\hline JS95 & $108.13 \pm 0.59$ & $3.05 \pm 0.06$ & 94.68 \\
JS99 & $111.01 \pm 0.07$ & $0 \pm 0$ & 97.21 \\
\hline
\end{tabular}

Table 1 . The effect of inactivating lactate dehydrogenase in the whole-cell catalyst JS95 on sugar recovery and lactate formation. JS99: the ldh deficient derivative of JS95.

Figure 1

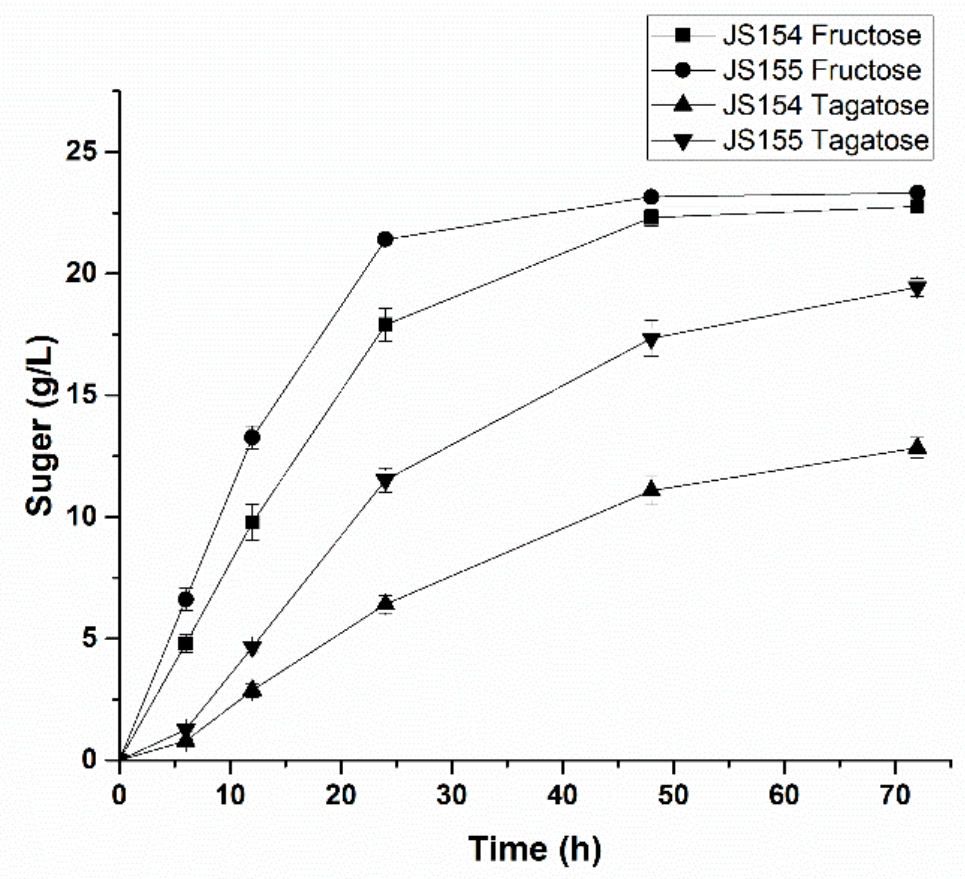

Figure 2 
A

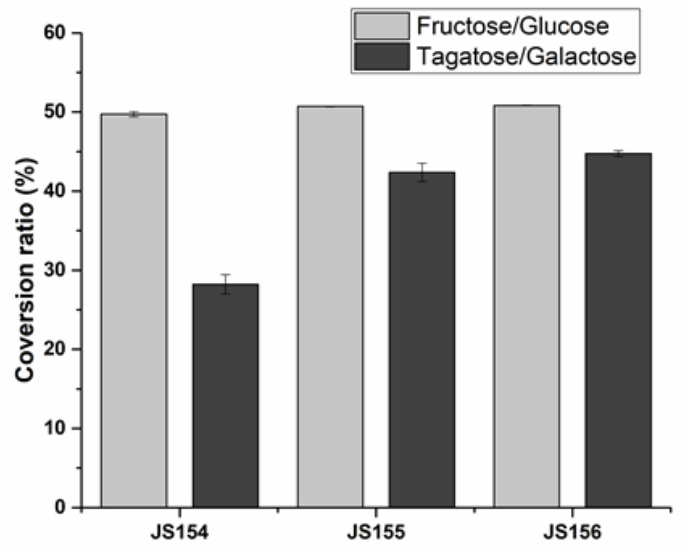

B

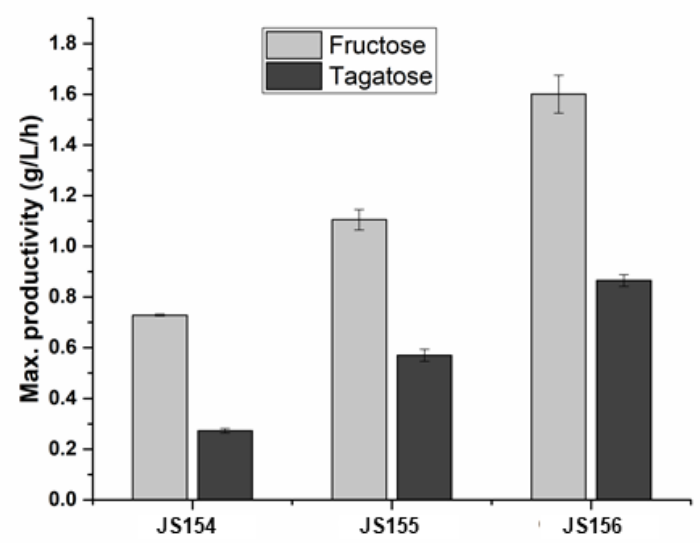

Figure 3

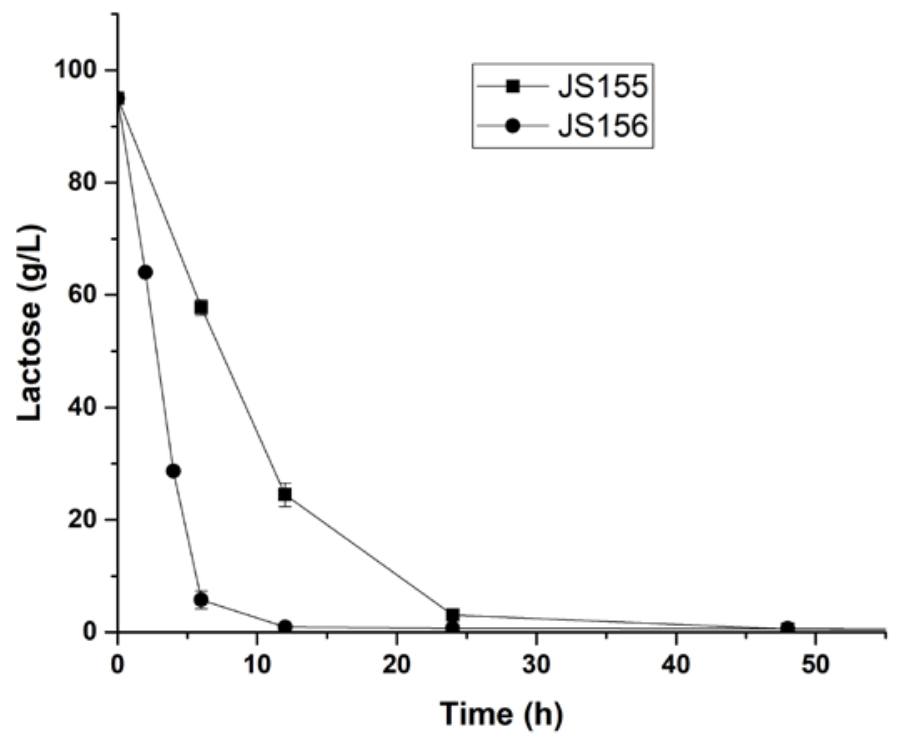

Figure 4 


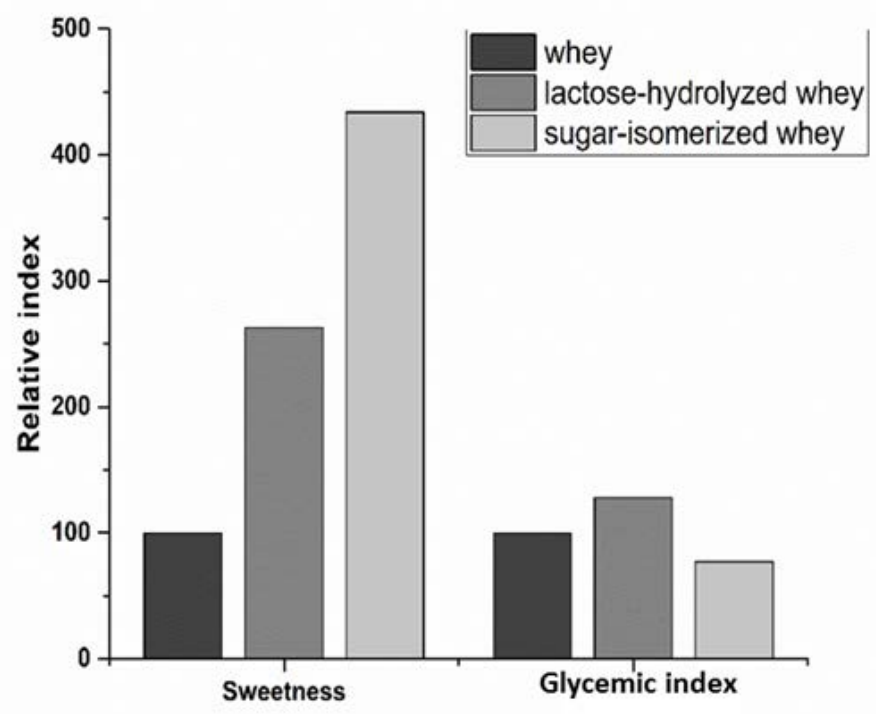

